\title{
Comparison of environmental loads with rail track systems using simplified life cycle assessment (LCA)
}

\author{
C. K. Lee, J. Y. Lee \& Y. K. Kim \\ Environment \& Fire Control Team, Korea Railroad Research Institute, \\ Korea
}

\begin{abstract}
Ballast track has some advantages compared to concrete track in terms of noise reduction, drainage and so on. However, rail infrastructure has been exchanged from ballast track to concrete track due to the ease of maintenance without considering prior environmental impact. In order to accomplish superior environmental position in the transportation modes, the environmental characteristics of rail track systems should be investigated, as well as the rail vehicle. In this study, two rail track systems, gravel ballast and the concrete track system, constructed recently on the Seoul-Busan High-speed Line for running KTX (Korea Train eXpress), were compared by quantifying their environmental loads using a LCA tool. The life cycle inventory of track systems was analyzed from their material and energy flows through a whole process. In the future, the application of LCA into railway infrastructure can achieve a fundamental technology for sustainable development.
\end{abstract}

Keywords: railway, track, life cycle assessment, sustainability, $\mathrm{CO}_{2}$ emission, $L C A$.

\section{Introduction}

Sustainable development is a key issue to shift from economic efficiency to ecological efficiency due to current environmental problems such as climate change from global warming. Environmentally-friendly goods and buildings are good examples. In the railway industry, many studies have been conducted to achieve a better environmental position in transportation. However, most of them 
are focused on rail vehicles (Wim et al. [1] and Walter et al. [2]) rather than infrastructure because the energy consumption of rail vehicles is relatively high. For sustainable development including the reduction of greenhouse effect gases, the entire railway system should be considered and analyzed.

Generally, rail infrastructure has a high initial cost for construction, and is maintained for a long time to secure the safe running of rail vehicle by checking periodically. Although railway facilities consist of various kinds of parts; bridges, tracks, tunnels and so on, there were some researches to quantify $\mathrm{CO}_{2}$ emissions using LCA and input-output analysis in Japan. Hiroshi et al. [3] tried to find the environmental effect of cross tie out of railway systems. Yoshihiro et al. [4] applied a LCA tool to Japanese high speed rail infrastructure including the bridge in the Tokaido Shinkansen line. However, these results were just to understand the $\mathrm{CO}_{2}$ emissions of each part of the railway system and were not carried out in the terms of sustainability. In order to construct a sustainable railway system, we investigate the parts with a greater environmental load and can show various suggestions to enhance the environment. However, it is difficult to assess the whole environmental load of each component in railway systems because there is too much variation. Thus, two railway track systems in this study were chosen to compare their environmental effectiveness. Currently, gravel track has been changed to concrete track in the railway industry because of easy maintenance and high economics. However, it is necessary to know which is more environmental-friendly and more sustainable. The results of this study are not intended to insist on which one is worse from the point of view of the environment, but which parts of system can be improved environmentally. Surely, after assessing a whole railway infrastructure including a bridge, we can know the environmental performance of the railway industry objectively and suggest the weak point environmentally. It can also influence the right direction environmentally in the planning stage of a new railway line.

\section{Life cycle inventory analysis}

\subsection{Goal and scope}

In order to quantify the environmental performance of a track system, a life cycle assessment (LCA based on ISO 14040 series) tool was applied. LCA is the only method to estimate the environmental impacts of target product quantitatively considering its whole stage from the production of raw materials to waste (called cradle to grave). It is essential to collect much information about the product to establish the life cycle inventory (LCI) database, which can deduce the environmental burdens of components, parts and a product through whole stages.

As mentioned previously, the high speed line among track systems constructed relatively recently in Korea was chosen as a target for LCA in this study. Typically, two track systems, gravel track and concrete track, exist for high speed rail: gravel track is usually constructed in tunnels and above bridges and concrete track covers the rest. To compare the environmental effects of two tracks, a functional unit (F.U.) was set along $1 \mathrm{~km}$ length of each track. On this 
basis, data was collected and converted for characterization. The system boundary was from the production of raw materials to the maintenance stage, with the exception of the dismantlement stage because of insufficient data.

\subsection{Life cycle inventory analysis}

The LCI of two track systems was performed according to the framework and procedures of ISO 14040 [5] and ISO 14041 [6]. Figure 1 shows a process tree of each railway track system. Data for each unit process were collected for the input and output parameters based on the cut-off criteria in the scope definition. Ballast, which can reduce noise and absorb vibration generated from the running of the railway, was used by the crushed gravel with specific physical characteristics such as hardness, size and so on. The crushed gravel is regularly supplemented because it is degraded and contaminated by oil from frequent railway running. Although there have been some researches to recycle and to reuse the polluted ballast, there is no technical standard for the disposal of blunt gravel but reclamation. On the other hand, the concrete track constructed according to the German Rheda system has many advantages from the point of view of maintenance, such as track cleaning and lining.

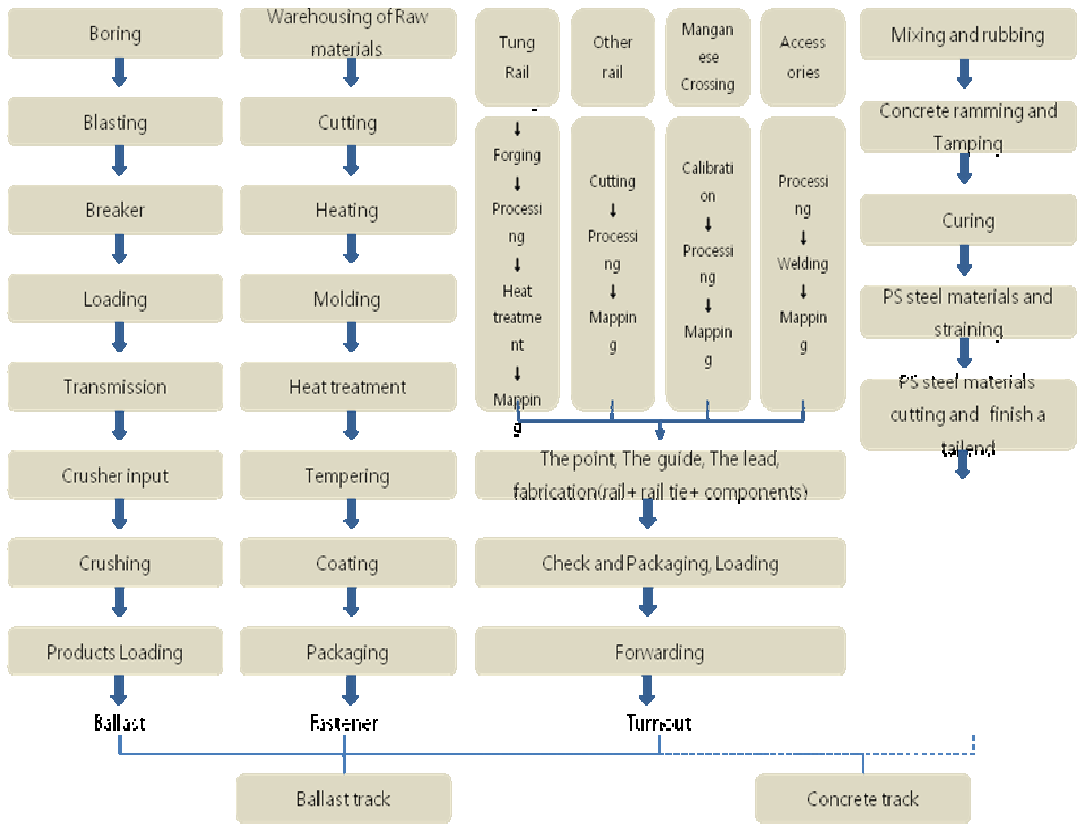

Figure 1: $\quad$ Major components and the manufacturing process of each track.

Table 1 summarises equipment and energy requirements to construct each $30 \mathrm{~km}$ of track. From these results, ballast track consumes more energy than concrete track. 
Table 1: $\quad$ Energy consumption of each track in the construction stage.

\begin{tabular}{|c|c|c|c|c|c|}
\hline \multicolumn{2}{|c|}{ Classification } & \multicolumn{2}{|c|}{ Ballast track } & \multicolumn{2}{|c|}{ Concrete track } \\
\hline & Equipment & Diesel (L) & $\begin{array}{l}\text { Gasoline } \\
\text { (L) }\end{array}$ & Diesel (L) & $\begin{array}{l}\text { Gasoline } \\
\text { (L) }\end{array}$ \\
\hline \multirow{3}{*}{$\begin{array}{l}\text { Track construction } \\
\quad(60 \mathrm{kgPCT})\end{array}$} & Motor car & 3,961 & - & 4,133 & - \\
\hline & Backhoe & 21,522 & - & 22,455 & - \\
\hline & Forklift & 6,298 & - & 6,571 & - \\
\hline \multirow{6}{*}{$\begin{array}{l}\text { Continuously welded } \\
\text { rail resetting }\end{array}$} & Rail cutter & - & 62 & - & 63 \\
\hline & Rail grinder & - & 270 & - & 276 \\
\hline & Rectification & - & 270 & - & 276 \\
\hline & Welding & - & 540 & - & 551 \\
\hline & Rail blow & - & 811 & - & 827 \\
\hline & $\begin{array}{l}\text { Power } \\
\text { wrench }\end{array}$ & - & 7,655 & - & 7,804 \\
\hline Rail cutting (60kg) & Rail cutter & - & - & - & - \\
\hline \multirow{2}{*}{$\begin{array}{l}\text { Ballast scattering } \\
\text { (mechanization) }\end{array}$} & Lifting & - & 15,422 & - & - \\
\hline & Backhoe & 344,718 & - & - & - \\
\hline \multirow{2}{*}{ Ballast tamping } & Tie tamper & - & - & - & - \\
\hline & Engine & - & - & - & - \\
\hline $\begin{array}{l}\text { Rail grinder } \\
\text { (rotary) }\end{array}$ & Rail grinder & - & 200 & - & 204 \\
\hline $\begin{array}{l}\text { Lighting (generator } \\
5 \mathrm{KW} \text { ) }\end{array}$ & Generator & 216 & - & - & - \\
\hline Concrete chipping & Compressor & - & - & 777 & - \\
\hline Total & - & 376,715 & 25,231 & 33,935 & 10,000 \\
\hline
\end{tabular}

\subsection{Life cycle impact assessment}

\subsubsection{Scenario}

It is difficult to collect data for life cycle inventory because there is no example of dismantling the whole track system after construction due to regular maintenance. For this reason, we created hypothetical scenarios to compare both tracks objectively. The main assumptions are as follows: The lifetime of each track is 20 years: The amount of materials and energy to maintain the track is about $1 \%$ of the initial construction stage. Table 2 illustrates the lifetime of components of the track. Based on these conditions, data including the operation frequency of equipment, energy, and so on, were also assumed.

\subsection{Impact assessment}

It is difficult to establish the environmental performance of each track with only the results of the life cycle inventory. After life cycle inventory analysis, life 
cycle impact assessment is conducted to analyze loads on the environment. As shown in table 3 , the ballast track system had a better environmental position by about 1.6 times compared to the concrete track, which resulted from the frequent maintenance of ballast track.

\section{Conclusion}

Concerning railway infrastructure, two track systems were selected in this study to assess environmental performance quantitatively and objectively. In Korea,

Table 2: $\quad$ Lifetime of major components.

\begin{tabular}{|c|l|}
\hline Component & \multicolumn{1}{|c|}{ Lifetime (year) } \\
\hline Rail & 30 \\
\hline Concrete & 30 \\
\hline Turnout & 30 \\
\hline \multirow{3}{*}{ Tongue rail } & 500 million ton: $50 \mathrm{~kg}$ \\
& 600 million ton: \\
$60 \mathrm{~kg}$ \\
\hline Clip & 20 \\
\hline \multirow{2}{*}{ Insulator } & 10 for ballast, \\
& 60 for concrete \\
\hline \multirow{2}{*}{ Pad } & 10 for ballast, \\
& 60 for concrete \\
\hline
\end{tabular}

Table 3: $\quad$ Impact assessment results of each track.

\begin{tabular}{c|c|c|c|c|c|c}
\hline \multirow{2}{*}{$\begin{array}{c}\text { Impact } \\
\text { category }\end{array}$} & \multicolumn{3}{|c|}{ Ballast track } & \multicolumn{3}{c}{ Concrete track } \\
\cline { 2 - 7 } & construction & maintenance & total & construction maintenance & total \\
\hline $\begin{array}{c}\text { Resource } \\
\text { depletion }\end{array}$ & $2.39 \mathrm{E}+05$ & $7.16 \mathrm{E}+04$ & $3.10 \mathrm{E}+05$ & $3.67 \mathrm{E}+05$ & $1.10 \mathrm{E}+05$ & $4.78 \mathrm{E}+05$ \\
\hline $\begin{array}{c}\text { Global } \\
\text { warming }\end{array}$ & $1.13 \mathrm{E}+05$ & $3.38 \mathrm{E}+04$ & $1.46 \mathrm{E}+05$ & $2.38 \mathrm{E}+05$ & $7.15 \mathrm{E}+04$ & $3.10 \mathrm{E}+05$ \\
\hline $\begin{array}{c}\text { Ozone } \\
\text { depletion }\end{array}$ & $8.45 \mathrm{E}+04$ & $2.54 \mathrm{E}+04$ & $1.10 \mathrm{E}+05$ & $1.91 \mathrm{E}+05$ & $5.73 \mathrm{E}+04$ & $2.48 \mathrm{E}+05$ \\
\hline $\begin{array}{c}\text { Photochemical } \\
\text { oxidant } \\
\text { creation }\end{array}$ & $1.71 \mathrm{E}+03$ & $5.14 \mathrm{E}+02$ & $2.23 \mathrm{E}+03$ & $3.48 \mathrm{E}+03$ & $1.05 \mathrm{E}+03$ & $4.53 \mathrm{E}+03$ \\
\hline Acidification & $3.72 \mathrm{E}+04$ & $1.12 \mathrm{E}+04$ & $4.84 \mathrm{E}+04$ & $6.11 \mathrm{E}+04$ & $1.83 \mathrm{E}+04$ & $7.94 \mathrm{E}+04$ \\
\hline \begin{tabular}{c} 
Eutrophication \\
\hline $\begin{array}{c}\text { Ecology } \\
\text { toxicity }\end{array}$
\end{tabular} & $1.37 \mathrm{E}+05$ & $4.10 \mathrm{E}+04$ & $1.77 \mathrm{E}+05$ & $1.87 \mathrm{E}+05$ & $5.60 \mathrm{E}+04$ & $2.43 \mathrm{E}+05$ \\
\hline $\begin{array}{c}\text { Human } \\
\text { toxicity }\end{array}$ & $2.13 \mathrm{E}+05$ & $6.38 \mathrm{E}+04$ & $2.77 \mathrm{E}+05$ & $3.13 \mathrm{E}+05$ & $9.40 \mathrm{E}+04$ & $4.08 \mathrm{E}+05$ \\
\hline \begin{tabular}{c} 
Total \\
\hline
\end{tabular} & $1.43 \mathrm{E}+06$ & $4.28 \mathrm{E}+05$ & $1.85 \mathrm{E}+06$ & $2.41 \mathrm{E}+06$ & $7.22 \mathrm{E}+05$ & $3.13 \mathrm{E}+06$ \\
\hline
\end{tabular}


Table 4: Contribution of environmental impact from each component of the track system.

\begin{tabular}{|c|c|c|c|c|c|c|c|}
\hline Ballast track & Rail & Tie & Ballast & Epoxy & Diesel & Gasoline & Fastener \\
\hline $\begin{array}{c}\text { Environmental } \\
\text { impact }\end{array}$ & $1.08 \mathrm{E}+04$ & $8.19 \mathrm{E}+05$ & $1.98 \mathrm{E}+05$ & $1.23 \mathrm{E}+03$ & $8.25 \mathrm{E}+03$ & $5.88 \mathrm{E}+02$ & $3.88 \mathrm{E}+05$ \\
\hline$\%$ & 0.76 & 57.44 & 13.87 & 0.09 & 0.58 & 0.04 & 27.23 \\
\hline Concrete track & Rail & Tie & Remicon & $\begin{array}{l}\text { Reinforcing } \\
\text { rod }\end{array}$ & Diesel & Gasoline & Fastener \\
\hline $\begin{array}{c}\text { Environmental } \\
\text { impact }\end{array}$ & $1.13 \mathrm{E}+04$ & $7.33 \mathrm{E}+05$ & $1.14 \mathrm{E}+06$ & $1.69 \mathrm{E}+05$ & $7.43 \mathrm{E}+02$ & $2.33 \mathrm{E}+02$ & $3.48 \mathrm{E}+05$ \\
\hline$\%$ & 0.47 & 30.46 & 47.55 & 7.03 & 0.03 & 0.01 & 14.45 \\
\hline
\end{tabular}

ballast track has been replaced with concrete track without environmental inspections. Although there is a regulation requiring prior environmental and economic assessment on construction, most of them are merely executed formally. In the railway industry, it is important to consider the environment of the infrastructure as well as material changes of tie, from ballast to concrete, to prevent an adverse effect on the earth. From this study, the environmental impact of concrete track was higher compared to ballast track, although it is more convenient for maintenance. In particular, it is important to consider the concept of environment during the design stage. In addition, LCA can provide information about a component or a process affected the whole environment loads, which is called as environmental performance index (EPI). In order to improve competitiveness of the railway industry and to reduce environmental burdens, it is essential to apply LCA tools including at the maintenance and abatement stage of rail track systems. Further, it is required to extend this target to other components, such as bridges, tunnels and stations.

\section{Reference}

[1] Wim, D., Joost, D. and Asa A., Toward a Sectorwide Design for Environment Support System for the Rail Industry, Environmental Management, 34(2), 181-190, 2004.

[2] Walter, S. and Wolfgang W., Green Line - strategies for environmentally improved railway vehicles, Advances in Life Cycle Engineering for Sustainable Manufacturing Businesses Proceedings of the 14th CIRP Conference on Life Cycle Engineering, 2007.

[3] Hiroshi, U., Taro T., Hideyuki, T. \& Manabu E., Fundamental Investigation of LCA of Cross Tie, QR of RTRI, 40(4), 210-213, 1999.

[4] Yoshihiro, Y., Seisin, M., Takahiro, Y., \& Yutaka, S., LCA of Shinkansen Civil Engineering Structure, RTRI report, 10(16), 7-12, 2002.

[5] ISO 14040:2006, Environmental management - Life cycle assessment Principles and framework.

[6] ISO 14041: 1998, Environmental management - Life Cycle Assessment Goal and Scope Definition - Inventory Analysis. 